IRSTI 06.35.51

Kargabayeva S.T. ${ }^{1}$, Berdaliyeva G.K. ${ }^{2}$, Kargabayeva D.T. ${ }^{3}$

\author{
${ }^{1}$ c.e.s., e-mail: k_sauleshka@mail.ru \\ ${ }^{2}$ c.e.s., e-mail: bernarberdali@gmail.com
}

${ }^{1,2}$ Ablai khan Kazakh University of international relations and world languages, Kazakhstan, Almaty ${ }^{3}$ Master of Technical Sciences, engineer-expert of the Limited Liability Partnership «Iasi Construction», Kazakhstan, Turkestan, e-mail: dkt1@mail.ru

\title{
THE NECESSITY OF FORMING SUPERFLEXIBLE COMPANIES IN KAZAKHSTAN
}

The article discusses the concept of «super-flexibility» and principles of super-flexible companies studied by H. Bahrami and S. Evans during their work in the Silicon Valley. Considering the pace and trends of Kazakhstan's business transformation the authors of the article have concluded that the principles and models of super-flexible organizational structures can become a methodological basis for managing companies in Kazakhstan and that would increase the country's competitiveness in the future. Companies that adhere to the principles of super-flexible companies will have the ability to quickly and effectively respond to the situation as well as be able to resist the pressure from the external environment. Based on the researches of $\mathrm{H}$. Bakhromi and S. Evans on superflexible companies, questionnaires were compiled and the first executives of the companies were interviewed, were revealed the prerequisites and necessity of forming superflexible companies in Kazakhstan. The authors concluded that if managers of companies in Kazakhstan will use the principles of super-flexible companies, they will be able to respond quickly to changes and will be able to take leading positions on the market.

Key words: economics, environment, structure, business, super-flexibility, principles of superflexible companies, adaptation, competitiveness.

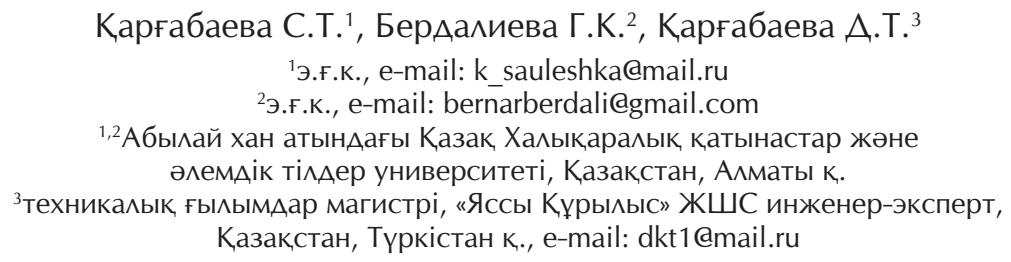

\section{Қазақстанда суперикемді компаниямарды қалыптастыру қажеттікіктері}

Мақалада Х. Бахрами және С. Эванспен Си^икон алқабында өз жұмыстарында зерттеген «суперикемділік» түсінігі және суперикемді компаниялардың қағидалары қарастырылған. Қазақстандағы бизнес трансформацияларының өсіңкіліктерін ескеріп, авторлар Қазақстан компанияларын басқару үшін суперикемді ұйымдастыру құрылымдарының қағидалары және модельдері әдістемелік негіз болатынына, ал ол деген келешектегі елдің бәсекеге қабілеттілігі артады деген қорытындыларға келді. Суперикемді компаниялардың қағидаларын қолданатын компаниялар жылдам және тиімді жағдайға жауап бере алады, сондай-ақ сыртқы ортаның әсеріне төтеп бере алады. Суперикемді компаниялар бойынша Х. Бахрами және С. Эванстың зерттеулері негізінде сауалнама сұрақтары құрастырылып, компаниялардың басшылары сұрастырылып, Қазақстандағы суперикемді компанияларды қалыптастыру қажеттілігі және алғы шарттары анықталды. Авторлар егер Қазақстанда компания басқарушылары суперикемді компаниялардың қағидаларын қолданатын болса, онда олар сыртқы ортаның өзгерістеріне жылдам жауап беріп, нарықта көшбасшылық позицияларды алады деген қорытындыға келді.

Түйін сөздер: экономика, қоршаған орта, құрылым, бизнес, суперикемділік, суперикемді компаниялардың қағидалары, бейімделу, бәсекеге қабілеттілік. 


\author{
Каргабаева С.Т. ${ }^{1}$, Бердалиева Г.К. ${ }^{2}$, Каргабаева А.Т. ${ }^{3}$ \\ ${ }^{1}$ K.э.н., e-mail: k_sauleshka@mail.ru \\ ${ }^{2}$ К.э.Н., e-mail: bernarberdali@gmail.com \\ ${ }^{1,2}$ Казахский университет международных отношений и мировых языков \\ имени Абылай хана, Казахстан, г. Алматы \\ ${ }^{3}$ магистр технических наук, инженер-эксперт ТОО «Яссы Строительство», \\ Казахстан, г. Туркестан, e-mail: dkt1@mail.ru
}

Необходимость формирования супергибких компаний в Казахстане

В статье рассматриваются понятие «супергибкость» и принципы супергибких компаний, изученные Х. Бахрами и С. Эвансом во время их работы в Силиконовой Аолине. Учитывая темпы и тенденции трансформации бизнеса в Казахстане, авторы статьи пришли к выводу, что принципы и модели супергибких организационных структур могут стать методологической основой Аля управления компаниями в Казахстане, что повысит конкурентоспособность страны в будущем. Компании, которые придерживаются принципов супергибких компаний, смогут быстро и эффективно реагировать на ситуацию, а также противостоять давлению внешней среды. На основе исследований Х. Бахрами и С. Эванса по супергибким компаниям были составлены вопросы анкеты и опрошены первые руководители компаний, выявлены предпосылки и необходимость формирования супергибких компаний в Казахстане. Авторы пришли к выводу, что если менеджеры компаний в Казахстане будут использовать принципы супергибких компаний, тогАа они смогут быстро реагировать на изменения внешней среды и занять ^идирующие позиции на рынке.

Кмючевые слова: экономика, окружающая среда, структура, бизнес, супергибкость, принципы супергибких компаний, аАаптация, конкурентоспособность.

\section{Introduction}

Today, in rapidly changing conditions, all businesses, one way or another, face the necessity of radical change in order to be both competitive and winning, or at least to survive in the competition.

The instability of the environment and the decline of oil prices (Gurkov, 2014) directly affect the development of our economy, which depends on the commodity sector. Depreciation of the national currency - tenge - which was recorded last time in February, 2014, when the National Bank decided to abandon supporting the tenge exchange rate (Capital - the center of Business Information, 2014), entailed economic consequences such as inflation, devaluation of savings, and decline in real wages of the population (Bahrami, 2010). Together, all of the mentioned events have undermined the assumption of stability and predictability. Economic problems worsen the existing difficult situation for businesses and doing business itself needs an effective application of knowledge that becomes a competitive differentiator in the business environment. Today foreign business leaders, academics and management consultants altogether recognize the change in business activity, and to make decisions new solutions are needed. It seems that now there is a need of applying one of the solution methods - creating superflexible companies.

\section{Materials and methods}

The main methods for conducting a descriptive study are analysis of secondary data; observations; polls; experiments. Of these methods for our research, we decided to use the survey method, conduct a survey of company executives to determine if there are any problems in managing companies, when everything is not stable in the business environment and you need to anticipate and make the right decisions in advance. We investigated 100 different Kazakhstani companies, regardless of size and type of activity, such companies as Almaty Management University, Bank Center Credit, Forte Bank, InoLingvo PC, 'Good' Agency, Sea Oil Company KazMunaiGaz in Aktau, Assorti Arena, Global Transport and Logistics, Mangistaunaygas, 'Novapetrol' LLP and etc. We have found out that not all companies in Kazakhstan are open, ready for communication and cooperation. Among the companies surveyed were mining companies, companies providing banking services, light and food industry companies, large funds and consulting agencies. Luckily, the leaders of these companies were ready for changes and cooperation. Thus, at the time we conducted the survey, we were in the exact time when the CEOs were looking for modification solutions. 
Factors affecting the development of the company were the years of foundation and the size of companies.

The tools of the marketing research are presented as the tests developed by the authors. The tests were developed on the basis of the study on American scientists H. Bahrami and S. Evans' theory.

Now let us analyze the companies we interviewed.

\section{Literature Review}

The authors of the concept of «super-flexibility» are two scientists from the United States - Homa Bahrami and Stuart Evans, who, relating to 25 years of experience of working with technology companies, presented cross-functional tool as a general guidance for developing an organizational strategy, for fulfillment of all basic managerial functions, and ultimately for ensuring that the company could become an organization that would use the concept of knowledge management for a better existence in a competitive market (Interview with Homa Bahrami and Stuart Evans, 2014).

In their interview with The European Business Review, the scientists have determined that this approach was more organic for small companies, and better if those companies were young and «... were not subjects to active influence of inertia and can experiment with new recipes» (Bahrami, 2005).

The essence of superflexible companies is the ability to quickly change the direction of development, adapt to the circumstances and make the right decisions in difficult conditions. "A superflexible organization is multipolar, like a living organism; it has a lot of unique individuals who move in the same direction, just like a flock of birds or a schoal of fish» (Bahrami, 2005).

To start business leaders need to know the concept of super-flexibility, its importance for their business, and the reason why a lot of attention should be paid to the structure of the organization.

Without going into details of the description of well-known organizational structures, we would like to point that in an unstable environment only the so-called «flexible» structures, those that can quickly re-orient production methods and business practices, have most chances of survival.

The term «flexibility» is a polymorphic concept (Interview with Homa Bahrami and Stuart Evans, 2014). Depending on the context, flexibility is interpreted differently in different sciences. In logistics on a par with the flexibility in supply chain management and software development, for example, the term "agility» (agility, agile supply chain) is used in the same way as in production of goods (agile manufacturing). In developmental psychology and ecology, the term «flexibility» (resilience) describes the process of returning to a standard state after the damage, and etc. Moreover, according to the authors, the term «super-flexibility» combines various similar terms and those various nuances into a comprehensive concept (Bahrami, 2005). A modern organization must meet all these qualities mentioned above: it must be nimble to win the competition and must be able to quickly recover from possible failures. Companies that adhere to the principles of super-flexible companies will have the ability to quickly and effectively respond to the situation as well as be able to resist the pressure from the external environment (Maralbayeva et al., 2016: 331-333).

Concepts such as adaptability, flexibility, robustness and reliability, elasticity, liquidity, flexibility, modularity and portability are related to the term «flexibility». Let us reveal the essence of these concepts.

The term «adaptability» is defined as «to fit to the conditions of the changed situation». This term is mostly often used as a synonym for 'flexibility'. Stigler (1939) was the first to spot the differences between the two terms. He suggested that the adaptability implies an optimal adaptation to the newly changed situation, while flexibility allows consistent, but temporary, approach to change. Stigler defined flexibility as an attribute of the production technology used for different products distribution at lower prices (Stigler, 1939).

The term was also used in the strategic management literature (Eppink, 1978) to describe the capability of an enterprise to respond to the envisaged changes, for example, when the forecasted scenario or restructuring of a large-scale industry becomes a reality.

The term «agility» describes the extent to which a company can quickly change the direction of its activities to avoid failure or to make its way to the unknown or to be an expert in its field. The term has been used in the literature to describe the characteristics of the organizational structure of the company (Hatum et al., 2003) and its IT infrastructure (Del Prete et al., 2003). During the last decades there has been an increased interest in flexible supply chain. The requirements for flexibility here are discussed in terms of diversity of the assortment, volume of production and logistics for the delivery of finished products. Agility in this case is perceived as a combination of speed and flexibility. 
The term «universality» means «the ability to find the use of products in various fields». Universality is achieved by the ability to respond to a wide range of changes in the economy, the company's capability to easily change directions and priorities. For instance, if the company was previously engaged in production, then, depending on the situation, it can currently switch to sales. If the company has previously focused on one particular market, it will become universal in case when it has the possibility to change the current market to a different one, thus being oriented to other customers.

The term "steadiness» is defined as the ability to withstand external impact, while maintaining the current state. In case if a company fails, this could mean its ability to heal itself.

The term «reliability» means a company's ability of withstanding the onslaught of competitors and changes in the economy being at risk conditions.

The term "plasticity» refers to the ability to easily change the shape. This allows the company to expand the scope of cooperation with other companies and to build relationships with competitors.

The term «liquidity» is defined as the ability of assets to be sold at market prices. In other words, those assets can be easily converted to another alternative form of wealth without any cost which may be associated with them.

Super-flexibility is very important for succeeding, because in the modern world, surprises can constantly occur and they force the company to deviate from its planned activities. In such situations, it may have neither enough time nor resources to take the necessary security measures.

How is it possible for organizations adapt to changes and respond quickly to internal and external pressures? This is primarily related to the development of new technologies and being ahead of competitors. Delays in responding to the impact of external factors lead to an accumulation of problems, loss of time and reduction of the company's competitiveness. Although earlier it was possible to predict the future with a sufficiently high degree of probability, now it is necessary make decisions without any forecasting, respond with high speed, and go a long way leaving competitors behind. Business leaders in Silicon Valley are looking for innovative principles that would help them rediscover themselves and thrive because of uncertainty. All these processes were investigated in Silicon Valley by professors Homa Bahrami and Stuart Evans (Bahrami, 2005).

When economy problems occur, an organization's super-flexibility is seen as the ability to adapt to new conditions (Interview with Homa Bahrami,
2014). On one hand, this means the ability to quickly refocus the company. On the other hand - it is the ability to withstand the uncertainty and follow a chosen direction, i.e., to have a fallback and move without changing the basic direction. Super-flexibility is a key to adapting in real time and prosperity in today's dynamic world.

There are five basic principles of super-flexibility that ensure processes to rebuild the team again and the opportunity to make it superflexible.

The first principle - is superflexible innovation: Why has Silicon Valley been successful, as the «innovation center» of the digital age? What can we learn from the experience of successful innovators in Silicon Valley? Professor Bahrami and supporters suggest the concept of «flexible utilization» (Bahrami, 2010), when a recycling process stimulates innovation and promotes entrepreneurship. This means that you need to learn from failures. After several attempts, companies should not give up the already established business, but they need to patiently look for other possible ways. Leaders must not punish unsuccessful projects, as they are just temporary setbacks, those that could provide a basis for future innovation.

The second principle - is superflexible strategies, those that should be focused on helping companies that have faced the problem of flexible response and the need to change the direction of development, i.e. the ability to switch from aggressive strategies to defensive ones and to wait for a while. Business leaders must maneuver their strategic direction, like an experienced driver while driving.

The third principle - it is superflexible performance that helps companies adapt to the current situation. Companies get feedback from customers and stakeholders and make decisions in accordance with the already obtained results.

The fourth principle says that superflexible organizations are multicentric, having several centers of gravity. This principle can help to explore the components of the organization and identify hot spots and distortions to enact more optimal approaches.

The fifth principle is about superflexible leadership that helps business leaders make better decisions, getting more widely accepted by users, improve the organization's morale, and reduce losses.

These principles provide a systematic methodology for rethinking the situation and prepare the ground for creating a clear plan for adaptation. Nowadays, the world is developing very fast, and now is the best time to apply these principles in companies in order to make them superflexible. 
Thus, a modern company that is flexible and possess the ability to respond quickly and effectively to the situation, must be reliable and stable, i.e. should be able to take a hit, to resist the pressure and be able to quickly recover from the brink of bankruptcy. A superflexible company may operate in various dimensions and depending on the situation it can be stable and reliable, and versatile and ductile. It is important that in case of such situations where it will be necessary to change the direction of its activity, the company should know how to remove potential sources of discord. The principles of super-flexibility lie in the fact that in the current uncertain conditions companies have to cultivate their ability to use different methods and possibilities to overcome this uncertainty.

Management features are defined on different grounds, such as, for example, national links of a company or institution, the organizational form of large or small enterprises, and building internal relationships within the organization. Features of the Kazakhstan management are generally defined by the principle of focusing on profit maximization (Konkova, 2014). Neither the businessmen nor the successful entrepreneurs have a unified point of view on what the management should be and on what it should be focused, as well as which management theory can serve as a basis for more effective management of the company. Thus, speaking at the «ASIA-2020» Ideas WorkShop held in 2012 in the International Academy of Business, Almaty, in order to identify the determinants of global trends for the coming decades and discussing the main trends of the Central and South-East Asia countries' development by 2020 , the founder of Singapore management University, President of the Singapore Institute of Technology, professor Tan Chin Tiong, PhD noted that it is needed to «implement good global practices that have already existed, but do not belong to anyone in particular and do not possess any identity» (Kondykazakova, 2012).

In this understanding, application of the principles of flexibility for local companies may be the most appropriate in terms of development of new relationships and connections in the organization. For Kazakhstan's business, where traits of centralization and the principles of collectivism have been observed, the source of which is the principle of a tribe in the national context (Zhunussov, 2014), to be more flexible for a timely response to changes in the environment means to keep up with the time and develop as leaders of the modern economy. For Kazakhstan, that has set challenging plans on eco- nomic development and innovation, the concept is a good model for the local companies' transformation into competitive players in the global market (Kargabayeva, 2014; Kargabayeva, 2015). The task for researchers, based on models such as the model of professors Bahrami and Evans, is to explore local companies and then subsequently develop recommendations for domestic enterprises on their transformation to superflexible organizational structures in order to be able to quickly respond to changes and take a leading position on the market.

\section{Results and discussion}

So now let us discuss the analysis of the companies surveyed by us. Out of $100 \%$ of the surveyed companies, $31.6 \%$ were founded in 2006 to 2010 , $26.3 \%$ are based on $2001-2005$, equally the companies established 1990-1995 and 1996-2000, equally between 1986 and $19895.3 \%$, after the collapse of the USSR, few companies that have survived and work, $5.3 \%$ are companies that were formed in 2011-2015. As can be seen from the diagram, the largest number of companies are companies that were formed in 2006-2010 and still continue to work, these were precisely those years when the global crisis occurred and companies independently sought ways of development.

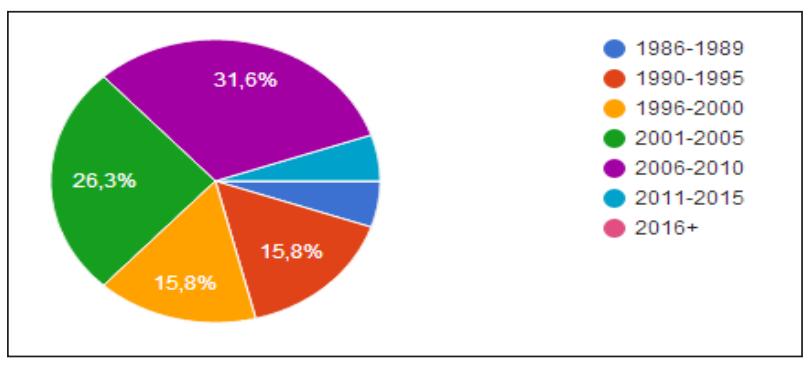

Figure 1 - Year of founding companies

Note - compiled by authors based on questionnaire analysis

Now we turn to the analysis of the forms of organization of companies, as can be seen from the diagram, the bulk of or $68.4 \%$ is limited liability partnership (LLP), 21.1\% are joint stock companies (SC), non-profit public institutions (NPI) and individual entrepreneurs (IP) are equal to 5.3\%. The most profitable and popular form of organization is LLP.

The next question of our questionnaire was «To which type of business do you belong?», and the small business accounted for the greatest number of answers, that is $52.6 \%$. The average business 
was $36.8 \%$ and large business occupies $10.5 \%$. Of course, small business companies were available for interviews.

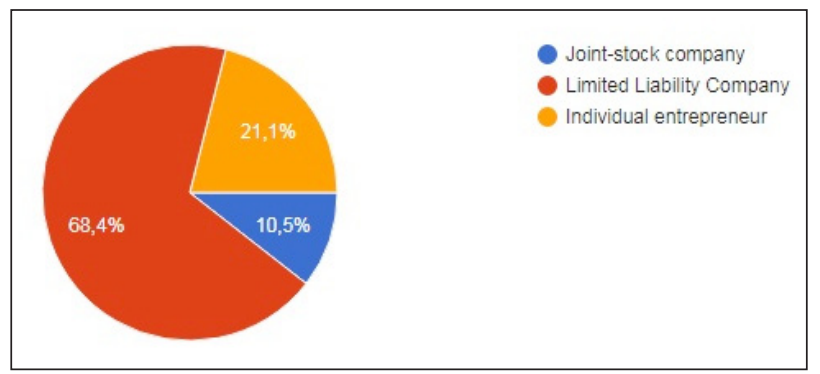

Figure 2 - Form of organizations of companies Note - compiled by authors based on questionnaire analysis

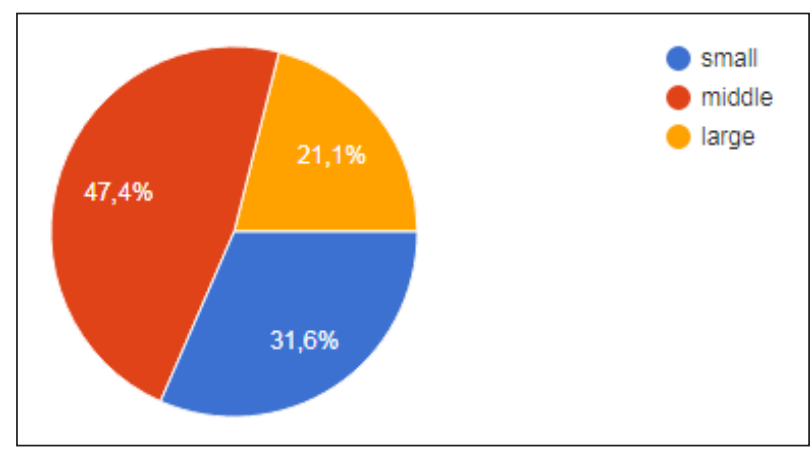

Figure 3 - Type of business

Note - compiled by authors based on questionnaire analysis

The largest number of employees in the surveyed companies is $11-50$ people, this is $31.6 \%$, then $21.1 \%$ - the number of people is $101-250$.

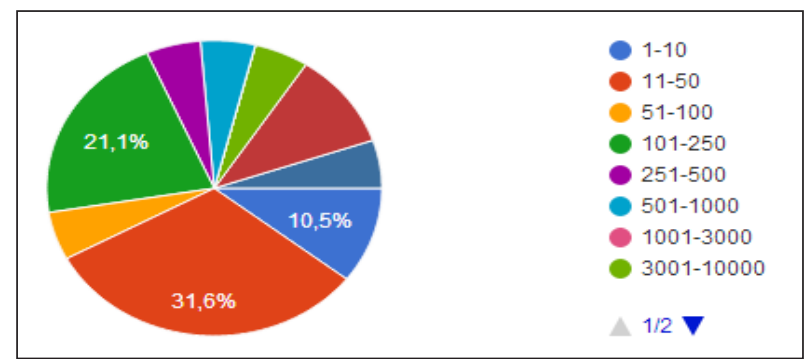

Figure 4 - Number of employees of companies Note - compiled by authors based on questionnaire analysis

In general, top management was surveyed, which was $78.9 \%$ and middle managers were $21.1 \%$. Of course, the survey was aimed at senior executives, as they could provide answers to our questions and take a direct part in decision-making. The interviewed managers held this position from
4 to 5 years and from 3 to 5 years equally $-21.1 \%$, from 1 to 3 years $-15.8 \%$, from 6 to 10 years, from 11-24 years and from 10- 25 amounted to the same $10.5 \%$.

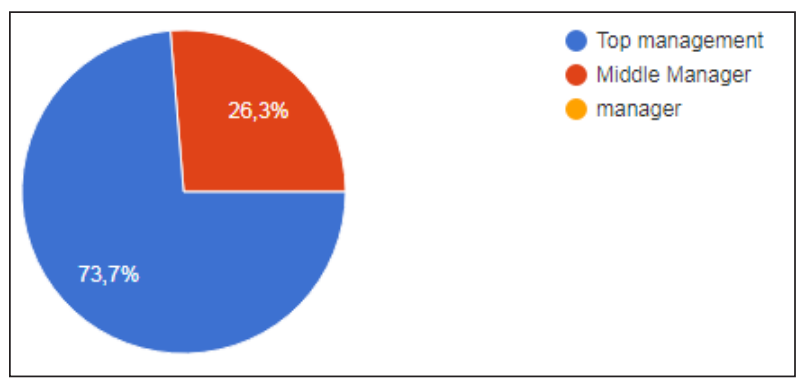

Figure 5 - Position of top management in the company Note - compiled by authors based on questionnaire analysis

Respondents answering the question «How would you define the "super-flexibility» of the company?» They gave the following answers:

- The ability of the organization to change depending on changing external factors and market requirements.

- Quickly change the profile of activity.

- Solve all problems.

- Changeability of the company due to the crisis, because of political, economic circumstances.

- Under any market circumstances, stay in business and provide services to consumers.

- A superflexible company must provide market demand. In what sense to be in the right place at the right time. This is the ability of the firm to different external conditions, the ability to adapt to the changing consumer demand and changing market conditions, while remaining afloat. Immediate response to environmental change and effective adaptation.

- The company's curiosity is the ability to change its own development strategy in time and to reach a new level of service delivery, the ability to find new customers on the market, to retain new ones and be able to make timely changes in order to preserve demand.

- Organization of work taking into account economic changes, the fruitful use of knowledge, to make the right decision in difficult circumstances, adjusting to circumstances, reducing the cost of production, effectively occupy the personnel.

- Loyal attitude towards the guests.

- Carrying out various promotions, discounts, entertaining programs for motivating and attracting guests. Material and cost part. 
- Price policy, attitude to the consumer, to feel the market.

- Go with time in one step. Monitor the trends in the services market. To anticipate the interests of consumers.

- For us, a company's "super-flexibility» is represented as a flexible work environment, through which we can respond in the fastest way to the demands of our business and satisfy our customers. Flexibility should be mutually beneficial: for both the employer and the employee, and lead to the highest results.

- Super-fast response to changes in the external and internal business environment.

- The ability of the company to adapt to sharp changes in the market, to change the structure, the form of the company.

- To adjust to foreign partners, skilled workforce, increase production capacity, meet international standards, obtain a quality certificate.

Respondents understand the essence of not only the flexibility of the company, but also the "superflexibility» of the company, they are ready to meet new realities, market trends, create new environment.

Answers to the following question: «What do you understand by» superflexible leadership «and is «super-flexibility» connected with leadership?» Were these:

- The ability to lead a team of companies to changes in a short time with the maximum effect.

- Leadership must be super-hard.

- The leader must be flexible in the process of change, and find ways out of the existing situations.

- Under uncertainty, adapt to the external environment and make decisions, taking into account all the factors.

- Leadership is the management of a company so that it is a superflex. Super-flexibility is to understand what the client wants and give him the best service. The company cannot be superflexible without having good managers.

- Superflexible leader is a person who manages everywhere and copes with the task very successfully. It is the leader who provides all employees with good conditions for productive work.

- We suggest that "super-flexibility» is not related to leadership. Being the leader in the production of specific services to the manufacturer, there is no need to expand production by absorbing new types of activities, adjusting to the quantity, and not the quality of the services provided.

- Leadership is directly related to the possibility of being a step ahead and in the constant search for new trends, i.e. be ready for change.
- Superflexible leadership is the ability to take responsibility for changing the company's development strategy during times of economic turmoil, the ability to adjust to new conditions for the functioning of markets, and be able to provide services that are relevant for a certain period of time.

- Finding a way out of the situation and make an acceptable decision. To gain authority in the team, «super-flexibility» is connected with leadership.

- It is connected, because the leader must combine flexibility in the management of personnel.

- Super-flexibility not always affects leadership, in particular, among a group of companies.

- These are two interconnected parts of one another, providing potential, market, professionalism, financial policy.

- Superflexible leadership implies great opportunities for rapid changes or adjustments in the company's operations. With leadership on the direct is not connected.

- «Super-flexibility» is a powerful and often inadequate tool for leaders. Thanks to superflex leadership, it is possible to better meet the needs of the organization and increase the efficiency of employees and the level of teamwork. "Super-flexibility» leader does not mean saying yes to all the wishes of subordinates. «Super-flexibility» primarily affects the attitude of the manager to employees offering new solutions for the performance of work. «Superflexibility» is the ability to create an open dialogue on how to work most effectively.

- Superflexible leader - leader - manager making effective decisions in the shortest possible time. Yes, it is.

- Instant decision making, solving the problem for the benefit of the company, in search of new, new sales channels, generate ideas, improve skills, improve, and evolve with the times.

- Establishment of contacts with personnel, solving staff problems, improving the aura in the team.

The answers are very diverse and interesting, but they all correlate "super-flexibility» with leadership. Some even defined the superflex leader. Undoubtedly, in a superflexible company there must be a leader who can convince his team to take on new risks, to look for new solutions.

Next, we suggested respondents to evaluate the statements on the scale of significance from the degree of absolute absence of importance (1) to the degree of absolute importance for the respondent (7). Answering the question: when the product becomes obsolete, I invent new products / services 
(add an additional property, functions to the goods / services) the company (my department, department), $52.6 \%$ of the respondents answered that this is very important.

The managers' response «To ensure quick and timely decisions, I create a consensus among experts and working groups», gave only $26.3 \%$, says that managers rely heavily on their risk and fear, rely only on themselves. The answer to the question «Super-flexibility is a critical ability for the head of the company» gives us another insight into the importance of the manager's abilities, $42.1 \%$.

But according to the answer that «I have a team that provides 'super-flexibility'» It can be judged that the leader still works in a team, and needs a team, as it can be seen from the answers given by $42.1 \%$.

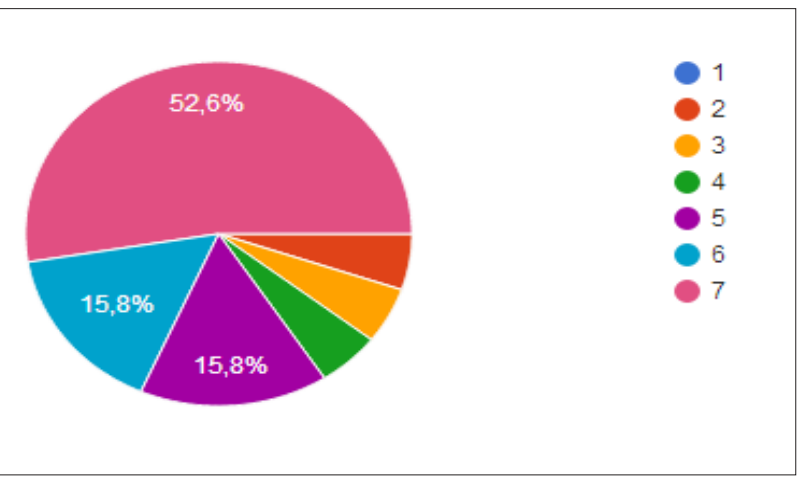

Figure 6 - The degree of importance in the event of product obsolescence, invent new products / services (add an additional property, functions to goods / services)

Notes: 1 . Compiled by authors based on questionnaire analysis

2. The scale of significance from the degree of absolute lack of importance (1) to the degree of absolute importance (7)

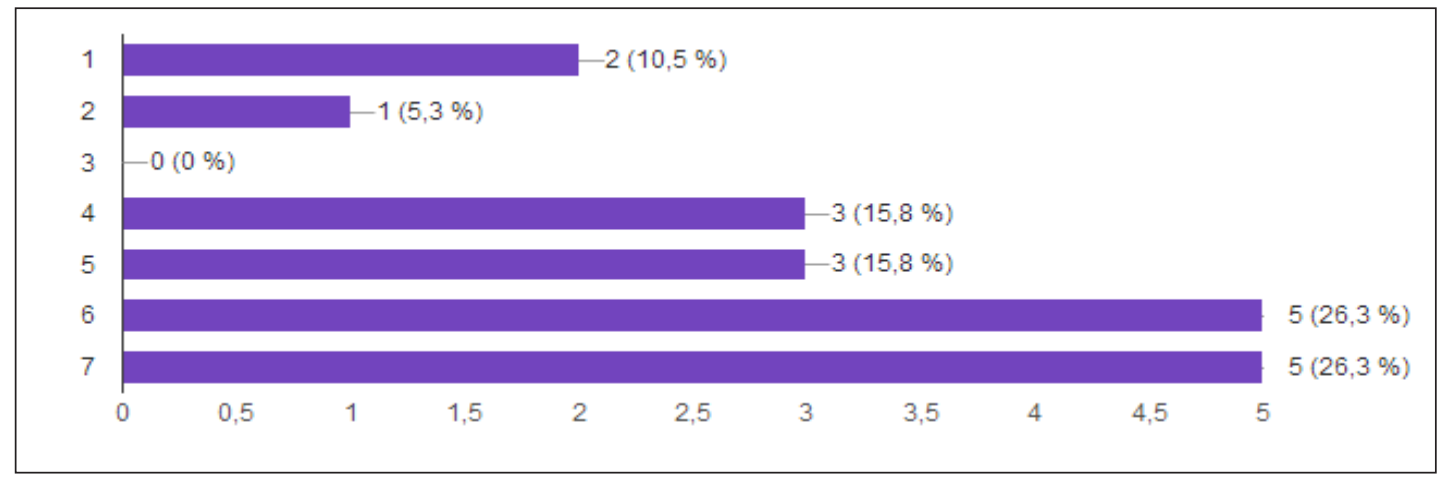

Figure 7 - The degree of importance of the ability of the head of the company Notes: 1 . Compiled by authors based on questionnaire analysis

2. The scale of significance from the degree of absolute lack of importance (1) to the degree of absolute importance (7)

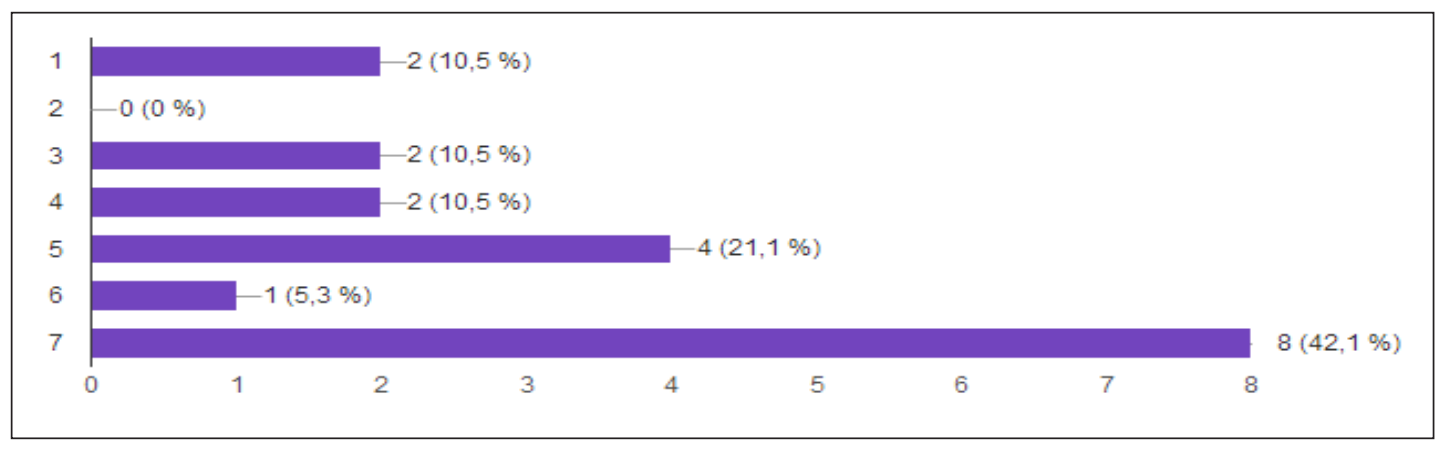

Figure 8 - The degree of importance of the team in the company

Notes: 1. Compiled by authors based on questionnaire analysis

2. The scale of significance from the degree of absolute lack of importance (1) to the degree of absolute importance (7) 
Answering the question «For me there is a big difference between the concepts of «super-flexibility», , adaptability», «agility», «maneuverability», «universality», «stability», «reliability», the leaders have made us understand that there are no sharp differences between these concepts, the result shows us only $31, \%$.

Answers to the questions: «My company can work in conditions of uncertainty» $(31.6 \%)$, «My management team with high (extreme) uncertainty can ensure the stability of the company» $(47.4 \%)$ and «My company can «go beyond», «My company establishes new models of development for themselves and does not limit its workers to established traditions» (36.8\%) let us know that our company is not superflexible enough and it is necessary to learn how to solve many problems in

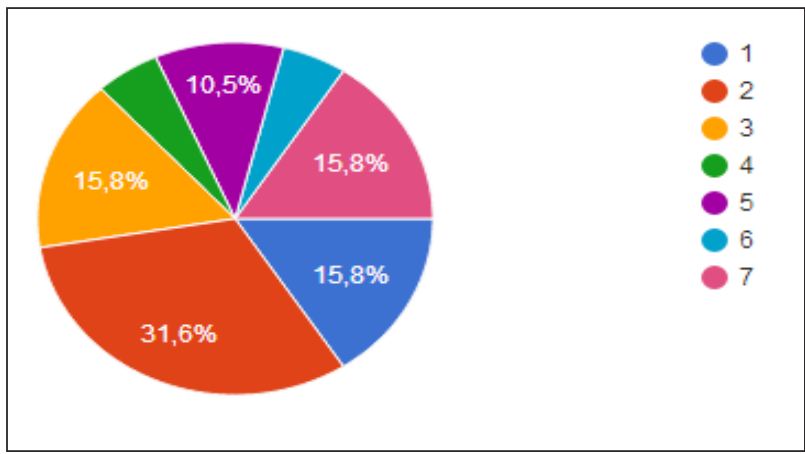

Figure 9 - The distinction between the concepts of «superflexibility», «adaptability», «agility», «maneuverability», «universality», «stability», «reliability»

Notes: 1 . Compiled by authors based on questionnaire analysis

2 . The scale of significance from the degree of absolute lack of importance (1) to the degree of absolute importance (7) extreme conditions.

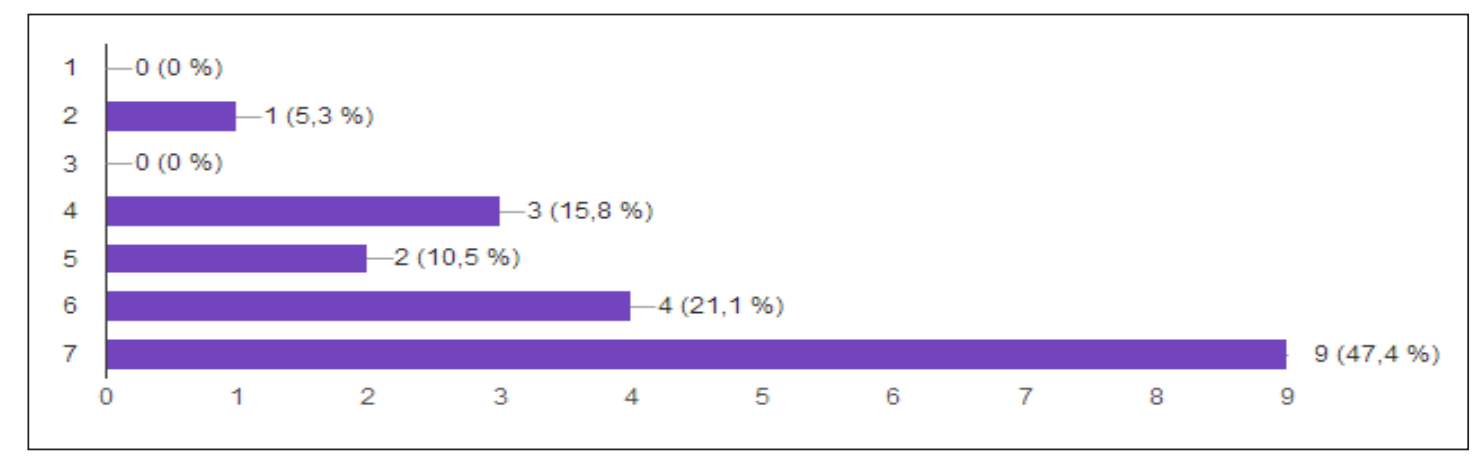

Figure 10 - The company's ability to work with high uncertainty and ensure the stability of the company Notes: 1 . Compiled by authors based on questionnaire analysis

2. The scale of significance from the degree of absolute lack of importance (1) to the degree of absolute importance (7)

Companies understand that in order to be competitive companies need to constantly change some things, constantly develop, reorient the resources at decisive points (57.9\%). And for this, a significant role of financing is necessary (47.4\%). It is also necessary to cooperate with competitors from the respondents we interviewed, $33.3 \%$ consider this question to be less important, the scale of significance here corresponds (4), we think that this is due to the fact that they do not yet trust competitors, and there is no need to cooperate with them.

Answering the question: «To solve simple problems, my company develops simple and standard templates» the respondents claimed on a scale of significance as ' 5 ' (38.9\%). This suggests that not all managers develop simple and standard templates for solving simple problems and this could save time for other tasks.
To the question: «To solve single, unique cases, my company develops individual approaches» respondents answered on a scale of significance as ' 7 ' $(33.3 \%)$, on the scale of significance (5) the answer to this question was $44.4 \%$. Of course, for such cases you need an individual approach, you need to think clearly about the solutions in such cases as well.

«My company's global plans are coordinated,» this is one of the signs of a super-flexible company, and company executives on a scale of importance (7) answered $36.8 \%$, this is the largest figure unlike other scales on this issue.

Answering the question «My company's shortterm and medium-term plans are balanced» in importance (7) and (1) scored the same number of answers $26.3 \%$. We think that not all managers clearly develop and coordinate their short-term and 
medium-term plans, and therefore many companies of Kazakhstan do not live long and leave the market, they think only of short-term profit.

«To meet today's realities, my company can reorganize in time»: this question characterized a superflexible company, and $31.6 \%$ of our respondents pointed ' 7 '. We can argue that, nevertheless, the largest number among the companies surveyed is a superflexible, in our conditions, when our country depends on the price of oil on the international market and the national currency is not stable. The answers to the following questions only prove the above mentioned «In times of crisis, my company can move around swiftly, change course, can use opportunities and bypass the threat, can withstand the blows and be stable», the response of respondents pointing ' 7 ' was $31.6 \%$. «In conditions of uncertain external environment and different socio-political and economic challenges for my company to be superfluous IMPORTANT» in terms of importance (7), respondents amounted to $73.7 \%$. Yes, we argue that in a situation of uncertain environment, it is necessary for a company to be superfluous, so as not to lose its place in the market, to confidently guide its business in the right direction, and of course, the role of the company's leader is very important.

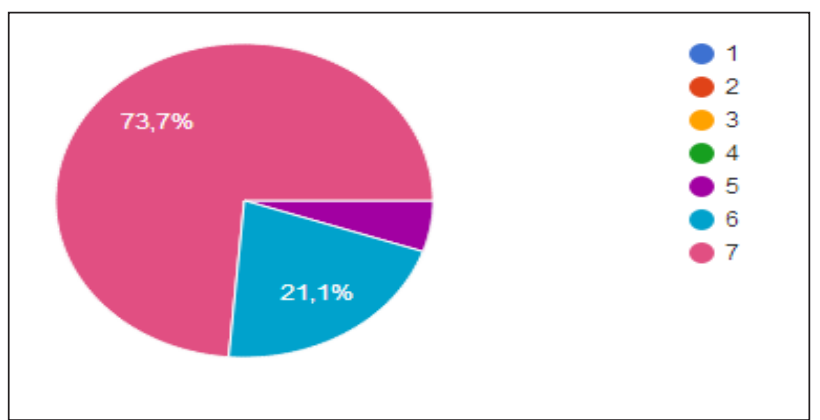

Figure 11 - The degree of importance of being a superflexible company

Notes: 1. Compiled by authors based on questionnaire analysis 2. The scale of significance from the degree of absolute lack of importance (1) to the degree of absolute importance (7)

Drawing conclusions, we are convinced that the companies that were formed in the years when the global crisis began (2006-2010) and continue to work independently looked for ways of development. During the crisis, newly created companies are more successful than those founded in a quiet period are. Such companies take off faster and have tremendous success, because the crisis gives opportunities for new business. The crisis affects poorly adapted or not super-flexible companies. Not super- flexible companies are those companies that have unjustified expenses, inefficient staff, a clumsy business, bureaucracy in the leadership, and any change in the market will immediately knock off most of such companies. Therefore, it is necessary to be more mobile, faster to turn in effective directions, instead of opening new ones, i.e. be super-flexible companies, and adhere to their principles, which we listed and described at the beginning of the article. A significant part of the businesses that flourished were discovered either in a crisis or immediately after it. When time passes, most of them get used to living in greenhouse conditions, and thus they become vulnerable.

\section{Conclusion}

Superflexible companies must have an efficient staff, in our Kazakhstani conditions, LLPs claim the names of such companies. In large companies, there is a bureaucracy, paperwork, decisions are strictly lowered from above, the lower state of affairs remains unknown, or these decisions go down for a long time, time is wasted, and the question is no longer relevant. In large state-owned enterprises, the state of things can be worse, because they relate to the company as non-owners, managers of such companies are not interested in the future of companies, because they know that they occupy their positions «temporarily» and at any time they will resign, so they do not think strategically, but live only for today.

Super-flexibility, according to American authors H. Bahrami and S. Evans (Interview with Homa Bahrami and Stuart Evans, 2014), is the ability to change the direction of their activities, to transform, develop and reinvent the new. At the same time, super-flexibility is not only about transformation and rethinking, it is also the ability to withstand the changing global economic, technological conditions, at times to come back and stay in the chosen direction, like a camel that survives in desert conditions. In practice, this means participating in a subtle balancing act: deciding what to save and how to stay in the chosen direction, on the one hand, and on the other hand, decide where to make quick and unexpected changes to address new realities. Although conducted research in Silicon Valley on the basis of analysis of IT companies, we think that these conclusions are applicable to our Kazakh companies, any activity. Managers, applying the proposals for the transition of their organization's activities to super-flexible organizations, they will be able to withstand in various 
changing global economic, technological, political, social, environmental conditions. Any superflexible company should exist in the global ecosystem, anticipate changes in advance and prepare several alternative solutions for different cases. In this case, the company does not waste time, thoroughly studies possible problems and makes the right decisions.

Our research showed that the managers and employees of Kazakhstan companies surveyed by us are ready to accept the conditions of superflexible companies. During the survey, we introduced them to the activities of American superflex companies, gave them definitions of super-flexible companies and on what principles such companies operate. We hope that after taking over the experience of world leading companies, Kazakhstani companies will be able to provide themselves with competitiveness and give a wide impetus to the development of the entire national economy.

\section{References}

Гурков А. Иран и сланцы: рухнут цены на нефть. - 2014.

Капитал - центр деловой информации. - 2014.

Информационный портал zakon.kz. - 2014.

Bahrami H., Evans S. Super-Flexibility for Knowledge Enterprises: A Toolkit for Dynamic Adaptation, 2nd ed. - Springer. 2010.

Interview with Homa Bahrami and Stuart Evans. 'Super-flexibility' is the capacity to transform by adapting to new realities, underpinned by the ability to withstand turbulence by creating stable anchors. -2014 .

Bahrami H., Evans S. Super-Flexibility for Knowledge Enterprises. - Springer. - Berlin, Heidelberg. - 2005. 327

Stigler G.J. Production and distribution in the short run // The journal of political economy. - 1939. - vol. 47. - No. 3, pp. 305-

Eppink D.J. Managing the unforeseen: a study of flexibility / Unpublished Ph.D. Dissertation. - Vrije Universiteit, Amsterdam. $-1978$

Hatum A., Pettigrew A.M. Adaptive Responses under Competitive Pressure: Organizational Flexibility in an Emergent Economy / Strategic Management Society Conference. - Buenos Aires. - 2003.

Del Prete C., Melenovsky M., Turner V., Waxman J. Enabling Business Agility: Hewlett Packard's Adaptive Enterprise Strategy. - IDC White Paper. - 2003.

Конкова К. Управление Республики Казахстан. - Национальный научный портал Республики Казахстан. - 2014.

Кондыказакова М. Менеджмент в Азии: тенденции ближайшего будущего // «Бизнес Life» Journal. - 2012. - №3 (57).

Жунусов С. Казахский менеджмент. Parts 1 \& 2 // Журнал «Промышленность Казахстана». - 2014.

Maralbayeva Sh.M., Kargabayeva S.T., Kargabayeva D.T. Models and principles of constructing superflexible companies / International conference on business and economics. - 2016, pp. 331-333

Каргабаева С.Т., Маралбаева Ш.М., Каргабаева Д.Т. Модели и принципы построения супергибких компаний // Научный и аналитический журнал «Наука и практика» РЭУ имени Г.В.Плеханова. - Москва. - 2014. - №2 (10).

Қарғабаева С.Т., Маралбаева Ш.М., Қарғабаева Д.Т. Суперикемді компанияларды құру қағидалары // ҚазҰУ Хабаршысы. - 2015. - №2.

\section{References}

Bahrami H., Evans S. (2005) Super-Flexibility for Knowledge Enterprises. Springer, Berlin, Heidelberg.

Bahrami H., Evans S. (2010) Super-Flexibility for Knowledge Enterprises: A Toolkit for Dynamic Adaptation, 2nd ed. Springer.

Del Prete C., Melenovsky M., Turner V., Waxman J. (2003) Enabling Business Agility: Hewlett Packard's Adaptive Enterprise Strategy. IDC White Paper.

Eppink D.J. (1978) Managing the unforeseen: a study of flexibility. Unpublished Ph.D. Dissertation, Vrije Universiteit, Amsterdam.

Gurkov A. (2014) Iran i slansi: ruhnut seni na neft [Iran and shale will collapse oil prices]

Hatum A., Pettigrew, A.M. (2003) Adaptive Responses under Competitive Pressure: Organizational Flexibility in an Emergent Economy. Strategic Management Society Conference, Buenos Aires.

Informasionyi portal [Internet portal] zakon.kz (2014)

Interview with Homa Bahrami and Stuart Evans (2014) 'Super-flexibility' is the capacity to transform by adapting to new realities, underpinned by the ability to withstand turbulence by creating stable anchors. 
Kargabayeva S.T, Maralbaeva Sh.M., Kargabayeva D.T. (2014) Modeli i prinsipi postroenia supergibkih company [Models and principles of building superflexible companies]. Scientific and Analytical Journal «Science and Practice» G.V. Plekhanov REU, Moscow, №2 (10).

Kargabayeva S.T, Maralbaeva Sh.M., Kargabayeva D.T. (2015) Superikemdi companialardi kuru prinsipteri [Principles building of superflexibility company]. The Journal of Economic Research \& Business Administration, vol. 2.

Kondykazakova M. (2012) Management v Asii: tendensii blijayshego budushego [Management in Asia: trends of the nearest future]. «Business Life» Journal, vol. 3 (57).

Konkova K. (2014) Management Respubliki Kazakhstan [Management of the Republic of Kazakhstan]. National scientific Internet portal of the Republic of Kazakhstan.

Maralbayeva Sh.M., Kargabayeva S.T., Kargabayeva D.T. (2016) Models and principles of constructing superflexible companies. International conference on business and economics, pp. 331-333.

Stigler G.J. (1939) Production and distribution in the short run. The journal of political economy, vol. 47, no. 3, pp. $305-327$.

Zhunussov S. (2014) Kazakhski management [Kazakh Management] Parts 1 \& 2. Journal «Industry of Kazakhstan».

Kapital - centr delovoi informasii [Capital - the centre of Business Information] (2014) 